\title{
The Effectiveness of Science-Based Learning towards Students' Understanding of Complex Analysis Courses
}

\author{
1Mariamah \\ ${ }^{1}$ STKIP Taman Siswa Bima, Bima, Indonesia \\ mariamah@gmail.com
}

\begin{tabular}{|c|c|}
\hline Article Info & Abstract \\
\hline $\begin{array}{l}\text { Article History } \\
\text { Received: July 12, } 2018 \\
\text { Accepted: September 30, } \\
2018\end{array}$ & \multirow{2}{*}{$\begin{array}{l}\text { The purpose of this study is to describe the effectiveness of science-based } \\
\text { learning drill towards students' understanding of complex analysis courses. } \\
\text { This research employed experimental procedure with one group posttest } \\
\text { design. The experimental group consisted of } 20 \text { sixth semester students } \\
\text { taking complex analysis courses. They were treated with drills on science- } \\
\text { based learning procedure followed with a post test that is composed of seven } \\
\text { questions. To measure the effectiveness of the procedure, } t \text {-test was applied. } \\
\text { With a standard value of } 70 \text { (value }=70 \text { ), the computation using SPSS } 16 \\
\text { program showed the } t \text { test results at a significant level of } 5 \% \text { was } 1.78, t \\
\text { table } 1.327, \text { and degrees of freedom (dk }=20-1 \text { ). Because } t \text { arithmetic is } \\
\text { greater than } t \text { table, the alternative hypothesis (Ha) is accepted. It can be } \\
\text { concluded from the statistical analysis that science-based learning drills are } \\
\text { effective to influence students' understanding of materials in complex } \\
\text { analysis courses. }\end{array}$} \\
\hline $\begin{array}{l}\text { Keywords } \\
\text { Scientific; }\end{array}$ & \\
\hline $\begin{array}{l}\text { Support by: } \\
\text { dol Crossref }\end{array}$ & \\
\hline
\end{tabular}

\section{INTRODUCTION}

Students are agents of change that need to be equipped with various knowledge and skills through the learning process. Students as well as prospective teachers are expected to be able to apply the knowledge they have acquired well. Complex analysis course is one of compulsory subjects for students of study program at STKIP Taman Siswa Bima, the purpose of this course is that students are expected to be able to master learning materials, creative and critical thinking so that later can apply science to solve various problems in daily life -day. According to Farhan and Retnawati (2004) mathematical learning plays a very important and essential role for the development of science and technology.

To achieve these goals, of course the various efforts that need to be done by a lecturer pengampu one of them is to use teaching methods that vary according to the characteristics of the material and students. Three years trakhir in every semester even, researchers always mengasok complex analysis courses and find out exactly the problems faced by students ranging from the understanding of student materials that vary, motivation and interest in learning is relatively less that encourages me to try the lessons that researchers have never done before using a self-directed scientific study.

The scientific approach is believed to be the golden tool for the development and development of students' attitudes, skills, and knowledge. Scientific-based learning approaches are more effective than traditional learning (Budiyanto, Waluyo\&Mokhtar, 2016, p.46)

Scientific approach makes learning more active and not boring, students can construct their knowledge and skills through the facts found in field investigations for 
learning. In addition, with this scientific-based learning approach, students are encouraged to be more capable in observing, asking, reasoning, and communicating or presenting the learned things of natural phenomena or direct experience (Kemendikbud, 2013: 203,212).

The scientific approach consists of five basic learning experiences: observing, questioning, gathering information / experiments, associating / processing information, and communicating.

According to (Mariamah\&Syarifudin, 2017, p 510) that driils are a repetitive exercise of the matter presented. In this research, the drier is the giving of practice questions continuously and giving the students an opportunity to answer the practice questions in front of the class

It can be concluded that scientific learning based on drift is a learning that is carried out based on the syntax of the scientific own that begins with giving the questions of the exercises.

\section{METHOD}

The type of this research is experimental research with one group postes design. The study was conducted in the sixth semester which is in charge of complex analysis course which only one class with 20 students. After doing treatments by applying scientific learning based on driils given post test. The instrument used to measure the mastery of student materials using the test instrument shaped esay as much as 7 questions. Data analysis to know the effectiveness of science-dried scientific learning against the understanding of the material using the t-test with a standard value of 70 (value $=70$ ).

\section{RESULT}

Based on the results of data analysis using the program spss.16 obtained the following results:

\section{One-Sample Test}

\begin{tabular}{|c|c|c|c|c|c|c|}
\hline \multirow{2}{*}{} & \multicolumn{2}{|l|}{ Test Value $=70$} \\
\cline { 5 - 7 } & $\mathrm{t}$ & Df & $\begin{array}{c}\text { Sig. (2- } \\
\text { tailed) }\end{array}$ & Mean Difference & \multicolumn{2}{|c|}{$\begin{array}{c}\text { 95\% Confidence Interval of the } \\
\text { Difference }\end{array}$} \\
\cline { 5 - 7 } & & & Lower & Upper \\
\hline NILAI & 2.517 & 19 & .021 & 5.00000 & .8416 & 9.1584 \\
\hline
\end{tabular}

The results showed that the test results using the SPSS program. 16 at a significant level of $5 \%$ obtained results of 2.517 and t table of 1.327 on degrees of freedom $(\mathrm{dk}=$ 20-1). Because $t$ arithmetic greater than $t$ table feeding hypothesis accepted is alternative hypothesis (Ha). From the results of the analysis can be concluded that scientific learning bebasisdriil effectively reviewed from the understanding of student materials in complex analysis courses.

The results of this study support the results of previous studies. (Budiyanto, Waluyo\&Mokhtar, 2016, p.46) states that traditional learning, acquisition of understanding by 25 percent. In scientific-based learning, the acquisition of understanding becomes $50-70 \%$. The drill method is one of the most suitable methods to apply to counting matter. The more often students complete the practice questions, the more familiar with the material being taught. So the application of science-based learning driil is effectively applied in learning to improve students' understanding of teaching materials. 
In the opinion of Endrayansyah (2014), Hosnan (2014), and Daryanto (2013) process learning by using approachScientific is much different from learningconventions in which the teacher is the sourceinformation students and teachers are always actively explaining,guide students until students understand. In a waythis is the time required in the student process fromdo not understand being understood takes timethe old, so less efficient. Inthe scientific approach of the teacher's problemalways based on the phenomenon that has beenoccurs in the lives of the students, then the students trylooking for answers to a given problemindependent.

\section{CONCLUTION}

Scientific learning bebasisdriil effectively reviewed from the understanding of student materials in the subjects of complex analysis with the value of $t$ arithmetic of 2.517 and $t$ table 1.327 at a significant level of $5 \%$.

\section{DAFTAR PUSTAKA}

[1] Budiyanto, M. A. K, Waluyo, L \&Mokhtar, A. (2016). Implementation of the Scientific Approach in Learning in primary education in Malang. Proceeding Biology education conference, 13 (1), 46-51. https://media.neliti.com/media/publications/176208-IDimplementation-system-dalam.pdf

[2] Budiyanto, Waluyo, Mokhtar. 2016. Implementasi Pendekatan Saintifik dalam Pembelajaran di Pendidikan Dasar di Malang. Proceeding Biology Education Conference (ISSN: 2528-5742), Vol 13(1) 2016: 46-51

[3] Endryansyah. (2014). Pengaruh Penggunaan Pendekatan Ilmiah (Scientific Approach) dalam Pembelajaran terhadap Hasil Belajar Siswa Kelas XII TIK I SMK Negeri 7 Surabaya pada Standar Kompetensi Mengoperasikan Sistem Kendali Elektro Magnetik. Jurnal Pendidikan Teknik Elektro, 03(02):25-29

[4] Farhan, M \&Retnawati, H. (2014). The effectiveness of pbl and ibl is evaluated from the learning achievement, the ability of mathematical representation, and the motivation to learn. Journal of Mathematics Education Research, 1 (2), 1-14

[5] Hosnan. (2014). Pendekatan Saintifik dan Kontekstual. Jakarta: Ghalia Indonesia

[6] Kemendikbud, 2013. Development of curriculum 2013. Exposure of education in socialization of curriculum. Jakarta: Kemendikbud.

[7] Mariamah \& Syarifuddin. (2017). Development of Textbook Analysis of Drill-Based Complex Problems to Develop Self-Released Character of Semester VI Students of Mathematics Education. Proceedings of the National Seminar of the Alumni Family Association (IKA) IKIP Mataram. 507-514 